CENTRE FOR COMPARATIVE ECONOMICS

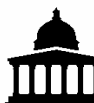

UCL SSEES

Centre for Comparative Economics

Entrepreneurship in Transition Economies;

The Role of Institutions and Generational Change

Saul Estrina and Tomasz M Mickiewicz ${ }^{b}$

${ }^{a}$ London School of Economics, UK

${ }^{b}$ University College London, UK, email: t.mickiewicz@ucl.ac.uk

Economics Working Paper No.106

March 2010

Centre for Comparative Economics UCL School of Slavonic and East European Studies Gower Street, London, WC1E 6BT Tel: +44 (0)20 76798519 Fax: +44 (0)20 76798777 Email: cce@ssees.ucl.ac.uk 


\title{
Entrepreneurship in Transition Economies; The Role of Institutions and Generational Change ${ }^{1}$
}

\author{
by \\ Saul Estrin \\ London School of Economics
}

\author{
Tomasz Mickiewicz \\ University College London
}

1 We are grateful to Paul Reynolds for sharing the consolidated 1998-2004 GEM data with us. Versions of this chapter were presented at UCL, Birkbeck College, University of East London, TIGER Conference in April 2009, the Italian Association for Comparative Economic Systems conference in Perugia and the University of Tartu. We gratefully acknowledge comments from an anonymous referee, Maria Minniti, Julia Korosteleva, Slavo Radosevic, and conference participants - Michael Keren, Greg Kolodko, Mario Nuti, and Milica Uvalic in particular. Any remaining errors are our own. We also acknowledge the EU support (Seventh Framework Programme, Theme 8, Grant 225134, Project EAGIS). 


\begin{abstract}
The transition economies have lower rates of entrepreneurship than are observed in most developed and developing market economies. The difference is even more marked in the countries of the former Soviet Union than those of Central and Eastern Europe. We link these differences partly with the legacy of communist planning, which needs to be replaced with formal market-supporting institutions. But many of these developments have now taken place, yet entrepreneurial activity still remains low in many places. To analyse this longer term issue, we highlight the necessarily slow pace of development of new informal institutions and the corresponding social attitudes, notably rebuilding the generalised trust. We argue that changes are even slower in the former Soviet Union than Central and Eastern Europe because communist rule was much longer, leading to a lack of institutional memory. We posit that changes in informal institutions may be therefore delayed until after full generational change.
\end{abstract}




\section{Introduction}

After a period of deteriorating performance, stagnation and recession in the 1980s, the command economy system finally imploded in 1989-1991. Communism had previously dominated a vast geographical area stretching from Berlin, Prague and Ljubljana in Central Europe to Ulan Bator and Vladivostok in Far East Asia, and its collapse leaves North Korea as the only surviving example of a traditional communist system in Euro-Asia (see Svejnar, 2002). While the old regime was based on a hierarchical, administrative mode of organising production coupled with detailed monitoring and surveillance of economic actors, a wave of reforms that followed aimed at establishing a market economy, with a significant role intended to be played by entrepreneurship. Drawing on the ideas of the Austrian economists (e.g. Schumpeter, 1934; Kirzner, 1973), many reformers viewed the creation of numerous new firms as the principal mechanism whereby the heavily industrialised structures of planning would be transformed into a market oriented system for allocating resources (see Kornai,1990; Djankov and Murrell, 2002).

The reforms of the early 1990 s however concentrated on stabilisation, liberalisation and the privatization of existing firms (Estrin, Hanuousek, Kocenda and Svejnar, 2009). Some countries, such as Poland and Slovenia, did display considerable entrepreneurial activity, but Aidis, Estrin and Mickiewicz (2008) show that entrepreneurship levels were in fact lower in the transition economies as a group than in the other developed and developing economies of the GEM sample. Moreover, the probability of becoming an entrepreneur was even lower in the Russia than in the other former socialist economies. These findings were consistent with numerous other studies (e.g. McMilllan and Woodruff, 2002; Estrin, Meyer and Bytchkova, 2006; Aidis and Mickiewicz, 2006) and, following the literature, we link them partly with the need to replace the legacy of communist planning with formal market-supporting institutions. However the aversion to entrepreneurship in many transition economies has deep roots and we use the change in informal institutions as our frame of reference. We highlight the necessarily slow pace of development of informal institutions and their effect on social attitudes, notably the low levels of generalised trust. We argue that changes of informal institutions have been even 
slower in the former Soviet Union than in Central and Eastern Europe because communist rule was much longer, leading to a lack of institutional memory. We posit that generational change may be needed before we observe such changes in informal institutions.

To explain the low levels of entrepreneurial activity, we first point to the weakness of institutions such as property rights enforcement (McMillan and Woodruff, 2002). The EBRD transition indicators (EBRD Transition Report, 19942009) show that implementing many aspects of the reform of formal institutions can be brisk, though arriving at a well-functioning set of new institutions takes much longer, largely because informal institutions are more difficult to change than formal ones (North, 1990). Thus the rapid pace of formal institutional change in transition economies during the 1990s was not matched by changes in informal institutions (Meier and Stiglitz, 2001). Moreover, the legacy of communism was not conducive to entrepreneurial activity (Estrin et al., 2006), as reflected not just in the remnants of the command economy, but more importantly by the social attitudes shaped during the communist period (Schwartz and Bardi, 1997).

We will posit that the level of generalised trust remains low in transition economies. That is probably an important explanation of why entrepreneurial entry has been found to be less common and why we observe the phenomenon of 'insider entrepreneurship' in the transition economies: new ventures are more likely to be started by those who have already established themselves in business (Aidis et al, 2008). We also find that the age profiles associated with entrepreneurial entry are distorted. Thus, being a member of the oldest age group has a significantly more negative impact on entrepreneurial entry in the transition economy than elsewhere. These findings have wider implications because they help us to understand the process of change in informal institutions. We suggest that in practice generational change may be required to bring about the shift in values and attitudes necessary for changes in informal institutions, thereby creating conditions more conducive to entrepreneurship.

The main contribution of this chapter is to develop these intuitions and to test them empirically using the Global Entrepreneurship Monitor (GEM) dataset 
(Reynolds, Bosma, Autio, Hunt, De Bono, Servais, Lopez-Garcia and Chin, 2005) combined with cross-country data about the quality of institutions, derived from the Heritage Foundation ( Aidis, Estrin and Mickiewicz, 2009). We first briefly summarise how the legacy that transition economies inherited from their communist past affects entrepreneurship. In the third section, we consider in more detail the implications for institutions, social attitudes and entrepreneurial entry rates. We illustrate cross-country differences using the GEM dataset combined with a variety of measures on formal and informal institutions. In the fourth section we test our hypotheses and present the results of our econometric analysis. Our approach is to explore how the process of transition affects some of the key drivers of entrepreneurial entry, notably indicators of formal and informal institutions as well as the age profile of entrepreneurs. We consider further developments and limitations in the concluding fifth section.

\section{The Legacy of Communism for Entrepreneurship}

Though transition opened many opportunities for entrepreneurship, the heritage from the planned era was in many ways not favourable (Estrin et al., 2006) and several aspects of the reform process acted to make the environment even less conducive to entrepreneurs. In this section, we review the evolution of the institutional, social and cultural environment for entrepreneurs in transition economies. We commence with the financial system, institutional barriers to entrepreneurship and the supply of human capital, before turning to social and cultural factors.

\subsection{The supply of finance and institutional obstacle to entrepreneurship}

Entrepreneurs require financial resources in order to establish and run their new firms (Hurst and Lusardi, 2004), and they must either provide this from their own (or family) saving, or borrow it from financial markets (Stanworth and Gray 1991; Storey 1994; OECD 2006; Beck, Demirgüç-Kunt and Maksimovic 2005; 2006; 2008). Neither of these sources was widely available in the transition economies initially. 
Under communism, individuals were not permitted to accumulate financial assets almost all wealth was owned by the state - and this was probably a major constraint on early entrepreneurial activity (Pissarides 1999). Moreover, financial markets were largely non-existent at the start of transition and progress in this area has been stubbornly slow in some places (EBRD Transition Reports, various years). According to the EBRD's transition indicators, progress in reform of the securities market and non-bank financial institutions has typically been modest; by 1994 only five countries had attained a ranking of 3 (which may be seen as the threshold level for successful reforms $^{2}$ ) for the capital market indices and the situation had not improved markedly by 2000 . Ten countries had not altered their category in the last five years and the situation had deteriorated in three - Russia, Slovakia and Slovenia. However, Poland and Hungary reached the top ranking of 4 and the Baltic States also improved somewhat. Moreover, the banking sector was inexperienced in private sector lending, and lacked the organizational capability to finance entrepreneurial businesses (Pissarides 1999). The evidence suggests that state owned banks continued to favour state owned firms and, to some extent also large privatized firms by providing soft loans (Lizal and Svejnar 2002) but rarely lent to the de novo private sector, particularly at the start of the transition process (see Richter and Schaffer 1996; Filatotchev and Mickiewicz, 2006).

Institutional obstacles to entrepreneurial activity were first highlighted by Baumol (1990) and have been explored in recent years by a number of economists including McMillan and Woodruff (1999, 2002), De Soto (2000), Djankov, Miguel, Qian, Roland and Zhuravskaya (2004) and Sobel (2008). Several institutional characteristics are argued to affect entrepreneurial endeavour: the quality of commercial code, the strength of legal enforcement, administrative barriers to entry and to business activities, the prevalence of extra-legal payments and a lack of

2 On a scale of 1-4, 1 represents little progress, 2 indicates a rudimentary exchange and legal framework, 3 means making some progress (securities being issued by private firms, some protection of minority shareholders and the beginnings of a regulatory framework), 4 means that countries have relatively liquid and well functioning securities markets and effective regulations and 4+ implies countries have reached the standard of advanced industrial economies. 
market-supporting institutions. Empirical work on the importance of legal enforcement is however not conclusive. Johnson, McMillan and Woodruff (1999) find that the entrepreneur's belief in the courts' inability to enforce contracts efficiently has a negative effect on employment growth, though this effect is not significant with respect to sales growth. Russian entrepreneurs have also been found to have less confidence than non-entrepreneurs in the efficiency of the court system (Djankov et al, 2004).

The legal and institutional system underlying a market economy was immature in transition economies, having only been introduced in many countries for the first time post-1990 (Svejnar, 2002). In this respect it is useful to draw a distinction between the countries of Central and Eastern Europe (CEE; which includes the three Baltic republics) and those of the former Soviet Union (FSU). ${ }^{3}$ As the literature has stressed (e.g. Djankov and Murrell, 2002; Estrin et al, 2009), the CEE economies for the most part inherited a stronger legal, institutional and cultural framework from the perspective of operating a successful market economy, partly because many CEE countries had thriving capitalist economies in the nineteenth century and the inter-war period. Moreover, this initial advantage was amplified by the process of Accession to the European Union, during which candidate countries adopted the legal codes and institutions of the Union (Bevan and Estrin, 2004). Thus, most of the CEE economies did have a commercial code in 1989, though it was typically outmoded; in terms of entrepreneurship for example, the new laws needed to define the concept of a private firm and to create procedures for entry and bankruptcy were usually adopted from the EU.

In contrast, those nations that became part of the Soviet Union when it was established in 1922 and remained so for seventy years had little or no experience of a market economy because communist planning and industrialisation were contemporaneous. As a result, laws and market supporting institutions had to be

3 Baltic republics of Estonia, Latvia and Lithuania were annexed by the Soviet Union on the basis of the German-Soviet Nonagression Pact of August 1939 and declared Soviet Republic. However, that was not recognised internationally. 
developed from scratch and without reliance on successful neighbours (there was no realistic prospect of EU Accession for these countries). Djankov and Murrell (2002) argue that these differential legacies explain the contrast in enterprise performance post-privatization in the two areas. In CEE, privatization generally led to enhanced performance while little or no impact was discerned in the FSU. The FSU also faced serious difficulties in operating a market economy immediately after the fall of communism. Thus, it was difficult to enforce voluntary contracts such as customers paying for the goods they had purchased or even firms paying workers their contracted wages (see Earle and Sabirianova 1998; Mickiewicz, 2009). In many countries, especially but not exclusively in the FSU, the state also continued to be very active and arbitrary in enterprise affairs, putting out its "grabbing hand" (Shleifer and Vishny 1999) to the detriment of new private ventures (Belka, Estrin, Schaffer and Singh 1995). This is particularly significant for our analysis because entrepreneurs are often more affected by corruption and ineffective regulatory frameworks because, in contrast to large firms, they lack bargaining power vis-à-vis the bureaucracy.

Taxes are a common complaint by entrepreneurs' worldwide (see Rosen (2005) for a survey of the effects on entrepreneurship). However, little distinction is made between the level of taxation and the methods of tax collection and enforcement. In transition economies, the costs created by an inefficient, inconsistent and/or corrupt system of tax collection may substantially add to the costs of running an entrepreneurial business. Some support for this can be found in Aidis and Mickiewicz (2006) who find that perception of high taxes ranks highest amongst the obstacles identified by small firms in Lithuania ${ }^{4}$.

\footnotetext{
$4 \quad$ However, their measure of taxation is correlated with two other variables- "frequent changes to tax policy" and "ambiguity of taxes" - suggesting that all aspects of the system of corporate taxation, rather than the level alone, may inhibit entrepreneurial growth.
} 


\subsection{Human capital}

Human capital is an important aspect of the supply of entrepreneurship (Davidson and Honig (2003)) and this is confirmed for transition economies by Barberis, Boycko, Shleifer and Tsukanova (1996) who show that new human capital was a crucial ingredient for successful new entry by small firms in Russia. In fact, the transition countries fare relatively well in terms of formal measures of education. The socialist regimes created extensive education and health services, and CEE economies continue to invest a high proportion of GDP in education, even outperforming some West European countries (Barr, 2005). As a result, literacy rates are high in transition economies and educational standards are comparable to Western Europe. Also, transition economies typically have a high proportion of students in 'hard' subjects of science, mathematics and engineering (Estrin et al., 2006). An important aspect of the human capital is also the age structure of the population as most entrepreneurs are in the age range of 30 to 45 and young customers are more likely to adopt new products and services. However, the demographic structure of CEE is now beginning to converge to that of Western Europe with relatively fewer young people.

\subsection{Social and cultural factors}

Informal institutions (that is: norms and values) are as important as formal institutions (that is: rules. i.e. norms combined with explicit sanctions) in shaping attitudes and economic behaviour, including entrepreneurship (North, 1990; Crawford and Ostrom, 1995). Research in the sociology of culture documents that communism left a legacy of values and norms that are not conducive to entrepreneurship. Sztompka (1996) describes this legacy as a 'bloc culture' which comprised priority of dependence over self reliance; of conformity over individualism; and of rigidity and extremism in beliefs over tolerance and innovation. He also notes that these norms are subject to a generational effect: "the bridge between the influences of the past and the future is provided by generations; congeries of people who - in their formative years - have happened to be exposed to similar, significant 
social forces" (Ibid., p. 126). This implies that changes in informal culture may be slow.

The same theme is developed and tested by Schwartz and Bardi (1997). They explain that the norms developed in the communist era were adopted mostly, not as an effect of direct indoctrination, but rather as a way of social adaptation to the prevailing economic and social conditions. Indeed their adoption was sometimes in direct contradiction to the official ideology. Thus, while the communist system officially promoted trust and cooperation, the prevailing conditions of surveillance and detailed monitoring of citizens led to distrust, which became deeply rooted in values and resulting social attitudes. Their empirical results confirm that values critical for entrepreneurship, which are clustered around autonomy and mastery, remained much weaker in post-communist societies than in comparator West European societies in mid-1990s.

Schwartz and Bardi (1997) identify cultural variation across different postcommunist societies. In their work, the countries of the former orthodox tradition score lower in terms of values conducive to entrepreneurship than Central European and Baltic states rooted in protestant and catholic origins. However, this distinction based on religious origin largely overlaps with the previously noted difference based on the time spent under Communism. The transition countries that went through the full cycle of communism from the end of World War I until late $20^{\text {th }}$ century, including the damaging Stalinist period (Applebaum, 2003) also score lower in terms of values conducive to entrepreneurship, as compared with those countries where Communism was introduced after the end of World War II. Similarly to Sztompka (1996), Schwartz and Bardi (1997) show that the differences between transition and comparator countries are lower for younger people, both because of the generational effect and the greater capacity of young people to learn and adopt to new conditions and cultural influences.

These findings are confirmed by the World Value Surveys, reported by Howard (2000). They show that in the transition economies, lack of generalised trust was partly substituted for by private networks in the communist era. However, these were no longer efficient as ways of dealing with the more sophisticated and larger scale 
market based economic activities post-transition; these needed to be based more on impersonal (generalised) trust.

Many aspects of entrepreneurship rely on cooperation in social milieu. This is important not only in the start-up phase, in particular with relation to entrepreneurial finance (see below), but also in the expansion phase, as a larger scale of operation relies on a more extensive network of contacts (Minniti, 2005). Thus, trust is an essential prerequisite for entrepreneurship but the transition countries share a negative heritage of a system based on authoritarian hierarchical organisation and detailed surveillance of all citizens. As stated by Fukuyama (1995): "There are indeed truly individualistic societies with little capacity for association. In such a society, both families and voluntary associations are weak ... Russia and certain other former communist countries come to mind".

To conclude, existing research suggests that post-communist societies, and especially members from the older generation, are characterised by a different set of values from that typically pertaining in developed market economies. In particular, autonomy and mastery score lower, and generalised trust is missing; moreover, the difference is more marked in the FSU than CEE. These values affect entrepreneurship directly and may also affect it indirectly via their impact on the way formal institutions function. In particular, lack of trust affects expectations and may result in a self-fulfilling vicious circle of poor institutional practices and corruption. 


\section{Entrepreneurial Entry, Attitudes and Institutions}

In this section, we compare the levels of entrepreneurial activity amongst the post-communist economies, and between them and the GEM world sample. We organise our discussion around the theoretical framework proposed by Williamson (2000), starting with a discussion of entrepreneurial outcomes and moving up to attitudes by which those actions are driven. In turn, the attitudes will be shaped by formal institutions and informal institutions, the latter forming the final chain in the analysis. At the end of the section, we consider finance separately, as it reflects the impact of both formal and informal institutions.

\subsection{Entrepreneurship in transition economies}

To illustrate the variation in entrepreneurial activity in transition economies, Figure 1 below reports the size of the micro, small and medium size enterprise sector (MSME) in those transition economies for which comparative data was available. Five years averages are taken to control for cyclical effects.

$<$ Figure 1>

It is interesting to look more closely at both ends of the spectrum. Starting from the bottom, we have Belarus, one of the countries that consistently scores lowest on the EBRD transition indicators (EBRD, 2008). Belarus represents a system where some limited liberalisation has been accompanied with strong element of centralised economic control retained by the government. Next from the bottom is Bosnia, a country which was torn apart by civil war and where basic economic stability is only slowly re-emerging. In turn, at the top end of the spectrum we find Slovenia, Poland and Kyrgyz Republic. The first two Central European countries are advanced in the reform process ${ }^{5}$. The Kyrgyz Republic illustrates another point.

5 They are also characterised by large residual state sectors: according to the EBRD estimates, $30 \%$ of GDP was still originating in the state sector in Slovenia and $25 \%$ in Poland in 2008 . This may indicate that the size of the entrepreneurial sector is not necessarily related to the pace of privatisation. New private firms may emerge regardless of privatisation, as long as liberalisation 
While Central Eastern Europe benefits from the positive impact on stability and coherence of the institutional framework of the EU, it is not impossible to create conditions conducive to entrepreneurship in the former Soviet bloc. The Kyrgyz Republic scores significantly higher on EBRD Transition Indicators (EBRD, 2008) than its two Central Asian neighbours, Tajikistan and Uzbekistan, and this corresponds well to the ranking illustrated by Figure $1^{6}$.

While the size of the MSMS sector can be seen as a proxy for entrepreneurship, new firm entry is at the core of the concept and to measure this we use GEM, an ongoing multinational project created to investigate the incidence and causes of entrepreneurship within and between countries. Data are generated by surveys, which rely on stratified samples of at least 2000 individuals per country. The advantage of the GEM methodology is that the sample is drawn from the whole working age population in each country and therefore captures both entrepreneurs and non-entrepreneurs. While data on business ownership and individual business financing are included, entrepreneurial activity is primarily viewed as new, nascent start-up activity. Nascent entrepreneurs are defined as those individuals between the ages of $18-64$ years who have taken some action toward creating a new business in the past year (see definition in Reynolds et al. 2005). To qualify for this category, these individuals must also expect to own a share of the business they are starting and the business must not have paid any wages or salaries for more than three months. Established entrepreneurs are defined as individuals who own or manage a company and have paid wages or salaries for more than 42 months (ibid.).

creates possibilities for new entry. What is also needed is the basic stability of the political and institutional framework, which makes the long term risk of entry lower (Estrin et al, 2009). Central European new EU member states and candidate countries. However, one has also to take into account the level of development: Kyrgyz Republic is a much poorer country than Slovenia or Poland, with a less sophisticated economic structure of production, and in such conditions even some limited progress with reforms may produce significant results in terms of entrepreneurship. 
Figure 2 presents country averages for both prevalence rates of nascent entrepreneurs (i.e. those currently involved in start-up activities) and ownersmanagers of young ventures (less than 3.5 years old), where those rates are taken over working age population,. We use country-level averages calculated over the period of 1998-2005. Also, we focus not just on differences between the transition economies, but compare them with other countries at the similar level of development (middle income) in Latin America (Argentina, Brazil, Chile, Ecuador, Mexico, Peru, Venezuela), Asia (China, Jordan, Korea, Thailand) and two economies from the closer neighbourhood of the EU, again relatively similar in terms of GDP per capita (Greece and Spain). Finally, we add two major high income Western EU economies (Germany and UK), and the United States.

$<$ Figure 2>

Comparing Figure 2 with Figure 1, we notice that the ranking of countries changes. While Poland retains its position as the most entrepreneurial amongst the transition countries, Slovenia is now relegated to the bottom of the list. Clearly, an extensive MSME sector may not be correlated with high entry rates. More interestingly, we may now see how the transition economies score in comparison to other countries. Entry rates in transition economies as presented on Figure 2 are low compared with the comparator countries from other regions of the world except the old EU.. Possibly, the most striking comparison relates to China, which shares a command economy past with the transition economies of Central Eastern Europe and Central Asia, yet is characterised by much higher entry rates. We will return to this comparison below.

\subsection{Attitudes}

An individual decision to enter an industry by creating a new firm is directly affected by that individual's attitudes. The entrepreneurial traits which are conducive to entry relate to confidence and willingness to accept risk of failure (Wadeson, 2006). Figure 3 presents the cross country heterogeneity (country averages), where transition countries are contrasted with the largest economies outside this group (for 
2008 GEM survey; see Bosma, Acs, Autio, Coduras and Levie (2008) for more details). We focus on two dimensions: the percentage of respondents declaring that fear of failure is not a factor that would prevent them from starting a new venture, and the percentage of respondents who believe they have the skills and knowledge to start a business.

$<$ Figure 3>

Commencing with the latter, we see no evidence that transition economies are systematically different from comparator countries. There is low confidence in own skills in Russia, but also in Japan. In contrast, the respondents in the Balkan nations seem to have a level of confidence in their own skills which is not dissimilar to United States, Mexico, Iran or India.

However, the fear-of-failure variable generates a distinctive pattern in which transition countries score lower. A typical respondent in a transition economy seems to be less willing to take risks associated with a potential new venture project. Why is this? We will return to this question, but first we need to consider in more detail the issue of institutions and to return to a basic categorisation of formal institutions. 


\subsection{Formal institutions}

Recent theories of entrepreneurship emphasise that the institutional environment affects attitudes and therefore the propensity to start a new business. In particular, Baumol (1990) emphasises the critical role of institutions in directing entrepreneurship, either to productive or to non-productive or even destructive activity. McMullen, Bagby and Palich et al. (2008) report results of empirical analysis where ten individual dimensions of the Index of Economic Freedom (Heritage Foundation / Wall Street Journal) are used to explain heterogeneity in entrepreneurship rates across nations. ${ }^{7}$ They conclude that as the measures of institutions are collinear, the next step would be to apply data reduction techniques to generate more concise measures of institutions; this should generate sharper findings on which elements of formal institutions are most relevant to entrepreneurship.

This approach is adopted subsequently by Aidis et al. (2009), who perform factor analysis on the same set of indicators of economic institutions (Heritage / Wall Street Journal; for methodology, see Beach and Kane, 2007); the choice being motivated primarily by the wide coverage. Aidis et al establish that formal institutions do have a significant impact on levels of entrepreneurial activity. Moreover, the data reduction techniques permit the large variety of related institutional indices to be reduced to two distinct groupings, which are denoted the "size of the state sector"8 and the "rule of law". . Figure 4 below reproduces the factor scores for the GEM countries with the transition economies highlighted. Given the communist planning

7 Please see McMullen et al. (2008) for a detailed discussion of the Index of Economic Freedom sub-indices and their likely relationship with entrepreneurship. They relate to: foreign trade regulations, taxes regimes, size of government expenses, inflation, restrictions on foreign investment, labour market restrictions, restrictions on business entry and operations, corruption and financial repression.

8 As measured mainly by both the extent of state expenditures and by taxes; it is measured in reverse order, as "limited state sector".

9 The key components are (highly correlated) measures of protection of property rights and of freedom from corruption. 
legacy, transition economies tend to have relatively larger state sectors and are characterised by weaker rule of law than comparator countries, though the two institutional characteristics are not in general highly correlated.

$<$ Figure 4>

A larger state sector will typically militate against entrepreneurial activity, both because of high taxation and via state expenditures (Henrekson 2005; Minniti, 2008). Taxes and welfare provision may affect entrepreneurial entry via their direct impact on expected returns to entrepreneurial activity and on its opportunity cost. High and increasing marginal level of taxes may weaken incentives for opportunitydriven entrepreneurship by reducing potential gains, while high levels of welfare provide alternative sources of income and therefore by increasing the alternative wage may reduce the net expected return to entrepreneurship. Taken together, we may hypothesise that a larger state sector will crowd out entrepreneurial activity. While transition countries have generally a large state sector, there are marked differences between CEE and the FSU in this respect. In particular, Russia and other neighbouring smaller economies in that region are characterised by smaller state sectors, which can be dated back to collapse of tax revenue in the 1990s and administrative difficulties (Mickiewicz, 2005). However, this is not reflected in entrepreneurship rates, as illustrated by Figures 1-3 above. Thus, for transition economies, we need to seek for additional explanations, and the institutional component of property rights ${ }^{10}$ may be a good point to start.

Harper (2003) emphasises that "the institution of private property ... has an important psychological dimension that enhances our feelings of ... internal control and personal agency, and it thereby promotes entrepreneurial alertness" (Ibid., p. 74). For entrepreneurship, it is also important that the property rights not only guarantee the status quo but also include the 'find and keep' component, which is essential for the aspects of entrepreneurship related to discovery, innovation and

\footnotetext{
10 We will initially proxy property rights directly using the Heritage Foundation measure but in our econometric work we will also alternatively use our "rule of law" factor.
} 
creation of new resources (Harper 2003). In the classic studies on entrepreneurship (e.g. Schumpeter, 1934 [1912]; Kirzner, 1973; 1979) strong property rights were not explicitly discussed, rather assumed, because of the focus on developed economies. The perspective changes once we consider a wider cross-country heterogeneity. More generally, strong property rights are constituted by credible constraints imposed on the arbitrary decisions by the executive branch of the government and by the independent and effective judicial system. This has been argued to exercise a fundamental positive effect on all economic activity, including entrepreneurship. Acemoglu and Johnson (2005) show that property rights institutions have pronounced effects on investment, financial development and long-run economic growth. Aidis et al. (2009) reveal that among various institutional indicators, the property rights system plays a pivotal role in determining entrepreneurial activity in low income and middle income economies. Johnson, McMillan and Woodruff (2002) provide evidence that weak property rights discourage entrepreneurs to reinvest their retained profits into business.

Figure 5 illustrates how the transition countries score on the property rights dimension. There are a number of international organisations that provide expertbased assessment of property rights. As property rights (and more generally, institutional quality) are highly correlated with GDP per capita, we present residuals from regression of property rights indicators on logarithm of GDP per capita (purchasing power parity). With Estonia as the most notable exception, the overwhelming majority of transition economies are located below the world sample reference line. Once again, the CEE countries score relatively well (though not Bulgaria and Romania). Two countries that have the smallest MSME sector (see Figure 1), Bosnia and Belarus, are also characterised by weakest protection of property rights. Russia and Croatia, which come next from the bottom, have also very low entry rates (Figure 2; data on MSME sector size was unavailable for those two countries).

$<$ Figure 5> 


\subsection{Corruption}

The corruption dimension of institutional quality is interesting because it is located at the intersection of formal and informal institutions, and is likely to have a significant impact on entrepreneurship (McMillan and Woodruff, 2002). Aidis and Mickiewicz (2006) argue that corruption is damaging to entrepreneurial activity and expansion as it increases the level of uncertainty and reduces entrepreneurial gains. As we already noted, the change in informal institutions is slower than in formal institutions and - accordingly - overcoming the heritage of the command economy system is more difficult. Corruption can be seen as a key outcome variable reflecting all institutional weaknesses in the economy, as it results from weak property rights, arbitrariness in state administration, weak judicial system, excessive and nontransparent regulatory frameworks but also prevailing social norms and (selffulfilling) behavioural expectations (Tanzi, 1998; Treisman, 2007; Aidt, 2009). Therefore, it can be treated as a proxy for overall institutional quality (Tanzi, 1998). An additional advantage of empirical measures of corruption is that, unlike property rights, these are not expert based but gathered via surveys of economic decisionmakers. ${ }^{11}$ Aidis and Mickiewicz (2006) provide evidence showing that corruption has been an important obstacle to business expansion in transition economies.

It can be argued that successful entrepreneurs can develop strategies that minimize the detrimental effects of negative informal institutional influences, through for example networking (Minniti and Levesque, 2008), but these adaptations come at a high cost (Aidis et al, 2008). This is probably a reason why we observe very low levels of entrepreneurship combined with greater reliance on informal networks and endemic corruption in Russia (Estrin et al., 2006). In contrast, the levels of entrepreneurship are higher in CEE and reliance on informal networks is less; moreover, though corruption still affects a significant percentage of enterprises in

11 While it can be argued that these perceptions are subjective, the issue is more apparent than real because these perceptions shape attitudes and behaviour, including entrepreneurial decisions. 
these countries the levels are less than in the FSU (Transition Report, 2009; Aidis and Mickiewicz, 2006; Aidis et al, 2008).

$<$ Figure 6>

We illustrate this dimension of institutional quality with Figure 6 below, which is analogous to Figure 5; we report regressions of freedom from corruption on logarithm of GDP per capita for the world sample and present residuals for the transition economies. Again, the data come from Heritage Foundation indicators. The results are broadly consistent with those on property rights; as before, the transition economies usually score below the world sample comparator line. Russia and Belarus come at the bottom of the transition economies group. We may note that for those two countries, high corruption is consistent with low scores on actual entrepreneurship (see Figures 1-2 above) and on lack of confidence towards starting a new business (see Figure 3 above). In contrast, Estonia and Slovenia are positive exceptions, apart from Moldova, there are the only two transition economies that score above the horizontal line representing a level of corruption expected at a given level of GDP per capita. While we have no data for Estonia for Figures 1-3, Slovenia also scores high both on confidence measure (Figure 3) and on number of small enterprises (Figure 1).

\subsection{Finance}

Finally, we now turn to finance, which is another important element of institutional quality for entrepreneurship that can be seen as conditional on more basic factors rooted in both formal and informal institutions. Figure 7 below, juxtaposes transition economies against GEM-survey countries along two 
dimensions: the prevalence of informal finance and the extent of formal finance (the latter captured by the ratio of bank credit to GDP). ${ }^{12}$

$<$ Figure 7>

The transition economies score poorly on both dimensions of the supply of finance, in contrast to some of the developed countries, where formal credit abounds (United States, Japan, United Kingdom) and to some of the developing countries where informal finance is extensive (Uganda, Jordan, Peru, Ecuador, Mexico; note however much lower scores for Venezuela, Argentina, Brazil and India). Possibly, the most interesting comparison is between the transition economies of the former Soviet block with China, which scores much higher both on formal and informal credit dimension and in line with smaller neighbouring Asian economies of Thailand, South Korea and Taiwan. The high prevalence rates of informal finance fuelling entrepreneurship in China have been noted by other researchers (Smallbone and Jianzhong, 2009).

As we discussed above, weak formal institutions in the transition countries may be partly substituted by strong private networks. Therefore, one might expect informal finance to play stronger roles in these countries as, for example in Latin America (see left upper part of Figure 7). However, this does not seem to be occurring and a limiting factor here may be the lack of personal wealth, as discussed in Section 2.

\subsection{Summary}

Building on the theoretical framework in Section 2, we presented descriptive cross-country statistics comparing entrepreneurship and various aspects of

12 One would expect some interdependence between formal and informal finance, as the former helps to develop the latter via savings opportunities (Korosteleva and Mickiewicz, 2008). 
institutional development. We established that entrepreneurial entry rates are lower in the transition countries as compared with comparator countries at similar level of development in Asia and Latin America. We posit that different attitudes are behind different entrepreneurial outcomes; in particular fear of failure with respect to starting a new business is higher in transition countries than elsewhere. In turn, both attitudes and observed entrepreneurial behaviour are conditioned by both formal and informal institutions. Property rights protection remains deficient in transition economies. The level of corruption, a phenomenon observed at a cross-section of formal and informal institutions, is high, especially in the FSU. All these dimensions affect access to finance. Supply of formal finance is relatively limited in all transition economies, perhaps because formal finance development is partially conditional on effective property rights protection. In countries outside the transition block (e.g. Latin America or Asia), formal finance for start-ups is to some extent substituted for by informal finance provided by family and friends. However, in transition countries, perhaps because wealth accumulation is a new phenomenon, the possibilities for informal finance are more limited.

\section{Estimation results}

In this section, we use the GEM and Heritage Foundation data (1998-2004) to explore more formally the three main ideas discussed above. The first hypothesis (H1) concerns the level of entrepreneurial activity, which we expect to be lower in transition economies than elsewhere including emerging markets at comparable levels of development, because of institutional weaknesses as well as social and cultural factors. We build on the descriptive statistics in the previous section, but control for institutional factors when testing for the transition/ non-transition economy differences. If differences in likelihood of entrepreneurial entry in transition as against non-transition economies are driven entirely by differences in formal institutions, the residual difference captured by the transition indicator variable (dummy) should be insignificant. If, as we expect, the transition dummy is significant, one interpretation would be that this is caused by differences in informal institutions 
that are not captured well in our Heritage Foundation dataset and are difficult to measure directly.

The second hypothesis $(\mathrm{H} 2)$ also relates to impact of informal institutions. Unfortunately, we have no good direct measures of norms and values with sufficient cross-country coverage; the studies we quote in Section 2 are all based on a very limited range of countries. We know however that change in informal institutions is embedded in generational change: it takes time to overcome the heritage of communism, which is deeply rooted. Therefore we test whether the likelihood of entrepreneurial entry declines at a much faster rate in transition countries than elsewhere at some point on age distribution.

Thirdly, as noted above, weak formal institutions in former communist countries were to some extent substituted for by informal social networks, though less so in the provision of finance. Aidis et al. (2008) notice that in Russia this phenomenon results in a higher likelihood that entrepreneurial activity will be associated with other business ownership by the same individual. They argue that this may be because those already in business can build network capital. Here we investigate if similar effects hold for transition economies as a whole as against the comparator countries $(\mathrm{H} 3)$.

We test these ideas using cross-individual cross-country probit equations in which the dependant variable is the probability of an individual being engaged in start up. We follow the literature in controlling for the individual's age, education, gender, previous involvement in business financing and existing business ownership. In addition, we consider whether differences in the level of entrepreneurial activity between countries can be explained by variation in the quality of formal institutions, utilising the two factors from our Heritage Foundation data-reduction exercise discussed above, namely the "rule of law" and "limited government ". We include logarithm of GDP per capita (assessed at purchasing power parity) to control for the overall level of development and annual GDP growth rate to check for push and/or pull effects associated with the business cycle as well as country level prevalence rates of informal finance computed as peer effect (see Wooldridge, 2002) based on country-years clusters from GEM. 
We test our hypothesis by introducing an indicator variable (dummy) for the transition countries $(\mathrm{H} 1)$, and next by multiplying it by individual age and age squared (H2) as well as by another indicator variable representing business ownership of a respondent $(\mathrm{H} 3)$. We confirm $\mathrm{H} 1$ if the transition country indicator variable retains some explanatory power in addition to the institutional variables; $\mathrm{H} 2$ if the interactive effects between the transition dummy and age are significant; and $\mathrm{H} 3$ if the interactive effects between the determinants of entrepreneurial entry (nascent entrepreneurship) using individual level and macro controls the transition dummy and business ownership are significant. Descriptive statistics are provided in Table 1, and estimation results in Table $2 .{ }^{13}$.

Our approach is to use probit methods to estimate the determinants of entrepreneurial entry (nascent entrepreneurship) using individual level, a variety of macro controls and the three sets of dummy and interactive variables. We use two specifications of the formal institutional variables. The first, in models 1 and 3 , are the individual Heritage Foundation indicators of property rights. In models 2 and 4, are the two factors extracted from the Heritage Foundation / Wall Street Journal indicators: the "Rule of Law" and "Limited Government". We are unable to include the size of the formal financial sector, because the variable is collinear with property rights.

We establish a clear impact from formal institutional variables on entrepreneurial activity. Thus in models 2 and 4, "limited government" has a positive significant coefficient implying that the size of the government has a clear-cut negative effect on entrepreneurial entry. Similarly in models 1 and 3 the direct measure, fiscal freedom, also has a positive significant coefficient (this is also measured on a scale from high to low fiscal freedom). However, the results suggest that entrepreneurial activity is not explained by the quality of formal institutions regarding property rights. In fact, the rule of law and the property rights variables in all four models are insignificant. This finding is consistent with Aidis et al., 2009, who suggest it may be caused by the inclusion in the regression of developed countries, in which variation in institutional quality plays a smaller role on entrepreneurial activity.

13 The design expands on that applied in Aidis et al. (2009). 
Turning to $\mathrm{H} 1$, we find that the transition indicator variable has a negative and significant sign in models 1 and 2, confirming the hypothesis. Thus, entrepreneurship is found to be significantly lower in transition countries, even when we control for institutional differences. ${ }^{14}$ We attribute this result to informal institutions and the fact that the communist heritage in norms and values is not consistent with entrepreneurial aspirations.

In models (3) and (4) we estimate entry equations with the additional interactive effects on age, age squared and the owner/manager to test $\mathrm{H} 2$ and $\mathrm{H} 3$. First, we are interested to investigate if impact of age profiles differs for transition and nontransition economies. The intuition is that the prior experience of command economy may produce a generational effect: for older people; entrepreneurial motivation may be weaker due to the fact that the older generation had no experience of free enterprise for most of its lifetime. Indeed, we find the age square term to have a much larger marginal effect in comparison to non-transition countries. While for nontransition economies the highest age point associated with likelihood of entry is about 35 years, it is shifted back to about 33 years in transition economies. Moreover, its rate of increase below this age is steeper in transition economies, which may reflect poorer access to wealth noted above. We also see a steeper decrease with age after the turning point, consistent with the generational effect discussed above. Marginal effects for interactive variables are not calculated well by standard estimations for non-linear models including probit (Ai and Northon, 2003). Therefore, to verify our results we run additional models separating transition and non-transition groups of countries (hence no interactive effects were used) and the results were entirely consistent with those reported in Table 2.

$\mathrm{H} 3$ considers the role of informal networks indirectly via the possibility of a differential impact of prior business ownership-management on new entry between transition and non-transition economies denoted with reference to Russia 'insider entrepreneurship' by Aidis et al.(2008). This is tested for the two sets of indicators of

\footnotetext{
14 Note however, that the significance of the transition dummy and its marginal effect on entrepreneurship are reduced when we use the institutional factor scores rather than Heritage Foundation direct measures, possibly because the former capture institutional variation better.
} 
institutional quality in models 3 and 4 . The coefficient on the interactive dummy is positive and significant, which confirms that in transition economies as a whole, prior business experience increases the probability that an individual will become a nascent entrepreneur. We interpret this result as being the consequence of the weakness of the institutional environment, which generates a stronger position for those who are already in business.

\section{Conclusions}

We have shown that the transition economies have lower rates of entrepreneurship than are observed in most developed and developing market economies. The difference is even more marked in the countries of the former Soviet Union than those of Central and Eastern Europe. We link these differences partly with the need to replace the legacy of communist planning with formal marketsupporting institutions. Many of these developments have now taken place, yet entrepreneurial activity still remains low in many places, which we associate with the slow adaptation of informal institutions, including attitudes and social norms.

In general, our findings are consistent with the perspective of institutional economics, as exemplified in particular by North (1990). While initiating dramatic changes in formal institutions may be difficult, implementation at one level can be relatively quick. However, it is far more difficult to get those formal institutions working well. The key reason for this is that they rely on the quality of administration and of the system of justice, and these are both conditioned in turn by the prevailing attitudes of those representing the state; moreover, expectations about the way the state functions may be self-fulfilling. We document that transition countries have low scores on expert-based assessment of protection and stability of property rights, and on survey-based indicators of corruption. Moreover, we also argue that in these economies, generalised trust was severely damaged during the command economy period, and is only recovering slowly. In addition, other values that are conducive to entrepreneurship including mastery, confidence and autonomy are also weak. Unfortunately, these effects are not captured well either by existing measures of 
formal institutions or by individual characteristics. We attempt to capture the impact of informal institutions in transition economies indirectly, as a joint transition effect that distinguishes entrepreneurship outcomes in those countries compared with others. Moreover, we discovered a clear-cut generational effect: it is the older generation that is far less entrepreneurial than its counterpart in other regions of the world. This is both a cause for concern and a source of optimism: a corollary is that the younger generation carry much less of the burden of the past. We have also shown that in transition economies outsiders (i.e. those without previous business connections) are less likely than elsewhere to create new ventures; a phenomenon that we labelled 'insider entrepreneurship'. This is again consistent with our stress on informal institutions: it is likely that prior business ownership comes with better access to key informal networks that facilitate business operation. An obvious limitation of our research is that we are still missing a comprehensive set that would capture values and norms in comparative perspective. One can partly rely on the World Value Survey, which is informing some of the sociological and political research we quote in Section 2, but its coverage is still not extensive and it is not focused on many of the values and norms that are most critical for entrepreneurship.

An obvious limitation of our research concerns establishing empirically the role of informal institutions on entrepreneurship in transition economies. This chapter has amassed considerable circumstantial evidence that informal institutions matter for entrepreneurship in transition economies. Thus, entrepreneurship levels are found to be significantly lower and this can only partly be explained by relatively weaker formal institutions. Moreover, there are considerable differences in various measures of informal institutions between transition and other economies, for example with respect to corruption, the supply of finance and personal attitudes to entrepreneurial activity such as the fear of failure. However, in the absence of any comprehensive cross-country dataset on informal institutions, we are unable to test the hypothesis directly. One can partly rely on the World Value Survey, which is informing some of the sociological and political research we quote in Section 2, but its coverage is still not extensive and it is not focused on many of the values and norms that are most critical for entrepreneurship. 
In terms of future work, our work suggests that levels of entrepreneurial activity may increase in transition economies when a new generation born and educated in a market economy grows to maturity. In particular, one might want to concentrate research attention on the potential role of migrants on the next generation of entrepreneurs in the transition economies. The younger generation is more mobile and there is a current wave of migrations from Central Eastern to Western Europe, which is already enhancing entrepreneurship in countries like UK and Ireland, but may also generating positive feedback effect for the home countries via returning migrants with new skills, sources of finance and new trade links.

\section{References}

Acemoglu, D. and S. Johnson (2005). 'Unbundling Institutions'. Journal of Political Economy, 113: 943-995.

Aidis, R. and T. Mickiewicz (2006). 'Entrepreneurs, Expectations and Business Expansion: Lessons from Lithuania'. Europe-Asia Studies, 58: 855-880.

S. Estrin and T. Mickiewicz (2008). 'Institutions and Entrepreneurship Development in Russia: A Comparative Perspective'. Journal of Business Venturing, 23: 656-672.

and (2009). 'Entrepreneurial Entry: Which Institutions Matter?', Centre for Economic Policy Research, Discussion Paper No. 7278.

Ai, C. and C. Norton (2003). 'Interaction Terms in Logit and Probit Models'. Economic Letters, 80, 123-129.

Aidt, T. (2009). 'Corruption, institutions, and economic development'. Oxford Review of Economic Policy, 25(2), 271-291.

Applebaum, A. (2003). Gulag; A History. New York: Doubleday.

Barberis, N., M. Boycko, A. Shleifer and N. Tsukanova (1996). 'How Does Privatization Work? Evidence from the Russian Shops'. Journal of Political Economy 104 (4): 764-791.

Barr, N. (2005) (ed.). Labor Markets and Social Policy in Central and Eastern Europe. Washington DC: World Bank. 
Baumol, W. (1990). 'Entrepreneurship: productive, unproductive, and destructive'. Journal of Political Economy, 98: 893-921.

Beach, W. and T. Kane (2007). 'Methodology: Measuring the 10 Economic Freedoms'. Washington: The Heritage Foundation. Retrieved March 5, 2009 http://www.heritagefoudation.org

Beck, T., A. Demirgüç-Kunt and V. Maksimovic (2005). 'Financial and Legal Constraints to Growth: Does the Firm Size Matter?'. The Journal of Finance, 60 (1): 137-177. , L. Laeven, and V. Maksimovic (2006). 'The Determinants of Financing Obstacles'. The Journal of International Money and Finance, 25: 932-952. and V. Maksimovic (2008). 'Financial Patterns Around the World: Are Small Firms Different?'. Journal of Financial Economics, 89 (3): 467-487.

Belka, M., S. Estrin, M. Schaffer and I. Singh (1995). 'Enterprise Adjustment in Poland: Evidence from a Survey of 200 Private, Privatized and State-owned Firms'. Centre of Economic Performance Discussion Paper, 223. London: CEPR.

Bevan, A. and S. Estrin (2004). 'The determinants of foreign direct investment into European transition economies'. Journal of Comparative Economics, 32 (4): 775-787.

Bosma, N., Z. Acs, E. Autio, A. Coduras, J. Levie (2008). Global Entrepreneurship Monitor. 2008 Executive Report. Babson Park, MA: Babson College, Universitad del Desarrollo and London Business School.

Crawford, S. and E. Ostrom (1995). 'A Grammar of Institutions'. American Political Science Review, 89 (3): 582-600.

Davidson, P and B. Honig (2003). 'The Role of Social and Human Capital amongst Nascent Entrepreneurs'. Journal of Business Venturing, 18: 301-331.

De Soto, H. (2000). The Mystery of Capital: Why Capitalism Triumphs in the West and Fails Everywhere Else. New York: Harper \& Row.

Djankov, S., and P. Murrell (2002). 'Enterprise Restructuring in Transition: A Quantitative Survey'. Journal of Economic Literature, 40 (3): 739-793.

, E. Miguel, Y. Qian, G. Roland and E. Zhuravskaya (2004). 'Who are Russia's Entrepreneurs'. Washington: The World Bank. Mimeo.

Earle, J., and K. Sabirianova (1998). 'Understanding Wage Arrears in Russia'. Stockholm Institute of Transition Economics Working Paper 139. 
Estrin, S., K. Meyer, M. Bytchkova (2006). 'Entrepreneurship in Transition Economies', in M. Casson (ed). The Oxford Handbook of Entrepreneurship. Oxford: Oxford University Press: 693-723. , J. Hanousek, E. Kocenda and J. Svejnar (2009). 'Privatisation in Central and Eastern Europe'. Journal of Economic Literature, 47 (3): 699-728.

EBRD (1994-2008). Transition Report. London: European Bank for Reconstruction and Development.

Filatotchev, I. and T. Mickiewicz (2006). 'Private Benefits of Control' and Debt Financing'. In T. Mickiewicz (ed.). Corporate Governance and Finance in Poland and Russia. Houndmills: Palgrave Macmillan: 159-176.

Fukuyama, F. (1995). Trust. New York: The Free Press.

Harper, D. (2003). Foundations of Entrepreneurship and Economic Development. Abingdon: Routledge.

Henrekson, M. (2005). Entrepreneurship: A Weak Link in the Welfare State. Industrial and Corporate Change, 14 (3): 437-467.

Howard, M. (2000). The Weakness of Postcommunist Civil Society. Journal of Democracy, 13 (1): 157-169.

Hurst, E. \& A. Lusardi (2004). 'Liquidity Constraints, Household Wealth and Entrepreneurship'. Journal of Political Economy, 112: 319-347.

Johnson, S., J. McMillan and C. Woodruff (2002). 'Property Rights and Finance', American Economic Review, 95: 1335-1356.

Kirzner, I. (1973). Competition and Entrepreneurship. Chicago: University of Chicago. (1979). Perception, Opportunity and Profit. Chicago: Univerisity of Chicago.

Kornai, J. (1990). Road to a Free Economy. Norton, New York.

Korosteleva, J. and T. Mickiewicz. (2008). 'Finance and Entrepreneurial Entry', Working Paper, 96. London: Centre for Comparative Economics, UCL.

Lizal, L., and J. Svejnar (2002). 'Investment, Credit Rationing, and the Soft Budget Constraint: Evidence from Czech Panel Data'. The Review of Economics and Statistics 84 (2): 353-370. 
McMillan, J. and C. Woodruff (1999). Interfirm Relationships and Informal Credit in Vietnam. Quarterly Journal of Economics, 114 (4): 1285-1320.

and (2002). 'The Central Role of Entrepreneurs in Transition Economies. Journal of Economic Perspectives, 16 (3): 153-170.

McMullen, J., D. Bagby and L. Palich (2008). 'Economic Freedom and the Motivation to Engage in Entrepreneurial Action'. Entrepreneurship Theory and Practice, 32 (5): 875-895.

Meier, M. and J. Stiglitz (eds.) (2001). Frontiers of Development Economics: The Future in Perspective. New York: Oxford UP and World Bank.

Mickiewicz, T. (2005). Economic Transition in Central Europe and the Commonwealth of Independent States. Houndmills: Palgrave Macmillan. (2009). 'Hierarchy of Governance Institutions and the Pecking Order of Privatisation: Central-Eastern Europe and Central Asia Reconsidered'. PostCommunist Economies, 21 (4): 399-423.

Minniti, M. (2005), 'Entrepreneurship and Network Externalities', Journal of Economic Behavior and Organization, 28 (2-3):1-27.

(2008). 'The Role of Government on Entrepreneurial Activity: Productive, Unproductive, or Destructive?'. Entrepreneurship Theory and Practice, 32(5): 779790.

and M. Levesque (2008). 'Recent Developments in the Economics of Entrepreneurship'. Journal of Business Venturing, 23 (6): 603-612.

North, D. (1990). Institutions, Institutional Change and Economic Performance. Cambridge: Cambridge University Press.

OECD (2006). The SME Financing Gap: Theory and Evidence, Paris: OECD Publishing.

Pissarides, F. (1999). 'Is the Lack of Funds the Main Obstacle to Growth? EBRD's Experience with Small and Medium-sized Businesses in Central and Eastern Europe'. Journal of Business Venturing, 14: 519-539.

Reynolds, P., N. Bosma, E. Autio, S. Hunt, N. De Bono, I. Servais, P. Lopez-Garcia, and N. Chin (2005). 'Global Entrepreneurship Monitor: Data Collection Design and Implementation 1998-2003'. Small Business Economics, 24: 205-231.

Richter, A., and M. Schaffer (1996). 'The Performance of De Novo Private Firms in Russian Manufacturing' in S. Commander, Q. Fan, and M. Schaffer (eds). Enterprise Restructuring Economic Policy in Russia. Washington, DC: EDI/The World Bank. 
Rosen, H.(2005), "Entrepreneurship and Taxation" in V. Kanniainen and C.

Keuschnigg, Venture Capital, Entrepreneurship and Public Policy. Cambridge: Mass, MIT Press: 251-269.

Shleifer, A., and R. Vishny. (1999). In The Grabbing Hand: Government Pathologies and Their Cures. Cambridge, MA: Harvard UP.

Schumpeter, J. (1934). The Theory of Economic Development. Cambridge, MA: Harvard University Press.

Smallbone, D. and X. Jianzhong (2009). 'Entrepreneurship and SME Development in The People's Republic of China', in L. Dana (ed.) Handbook of Research and Entrepreneurship in Asia. Cheltenham: Edward Elgar.

Sobel, R. (2008). 'Testing Baumol: Institutional Quality and the Productivity of Entrepreneurship. Journal of Business Venturing, 23: 641-655.

Stanworth, M. and C. Gray (1991). Bolton 20 Years on - The Small Firm in the 1990s. London: Paul Chapman Publishing.

Storey, D. (1994). Understanding the Small Business Sector. Routledge: New York.

Svejnar, J. (2002). 'Transition Economies: Performance and Challenges'. Journal of Economic Perspectives, 16(1): 3-28.

Schwartz, S. and A. Bardi (1997). 'Influences of Adaptation to Communist Rule on Value Priorities in Eastern Europe'. Political Psychology, 18 (2): 385-410.

Sztompka, P. (1996). 'Looking Back: The Year 1989 as a Cultural and Civilizational Break'. Communist and Post-Communist Studies, 29 (2): 115-129.

Tanzi, V. (1998). 'Corruption around the World: Causes, Consequences, Scope and Cures', IMF Staff Papers, 45: 559-694.

Treisman, D. (2007). 'What Have We Learned About the Causes of Corruption from Ten Years of Cross-National Empirical Research?', Annual Review of Political Science, 10: 211-44.

Wadeson, N. (2006). 'Cognitive Aspects of Entrepreneurship; Decision-maiking and Attitudes to Risk'. In M. Casson (ed). The Oxford Handbook of Entrepreneurship. Oxford: Oxford University Press: 91-113.

Williamson, O. (2000). 'The New Institutional Economics: Taking Stock, Looking Ahead'. Journal of Economic Literature 38 (3): 595-613.

Wooldridge, J. (2002). Econometric Analysis of Cross Section and Panel Data. Cambridge, MA: MIT Press. 
Figure 1

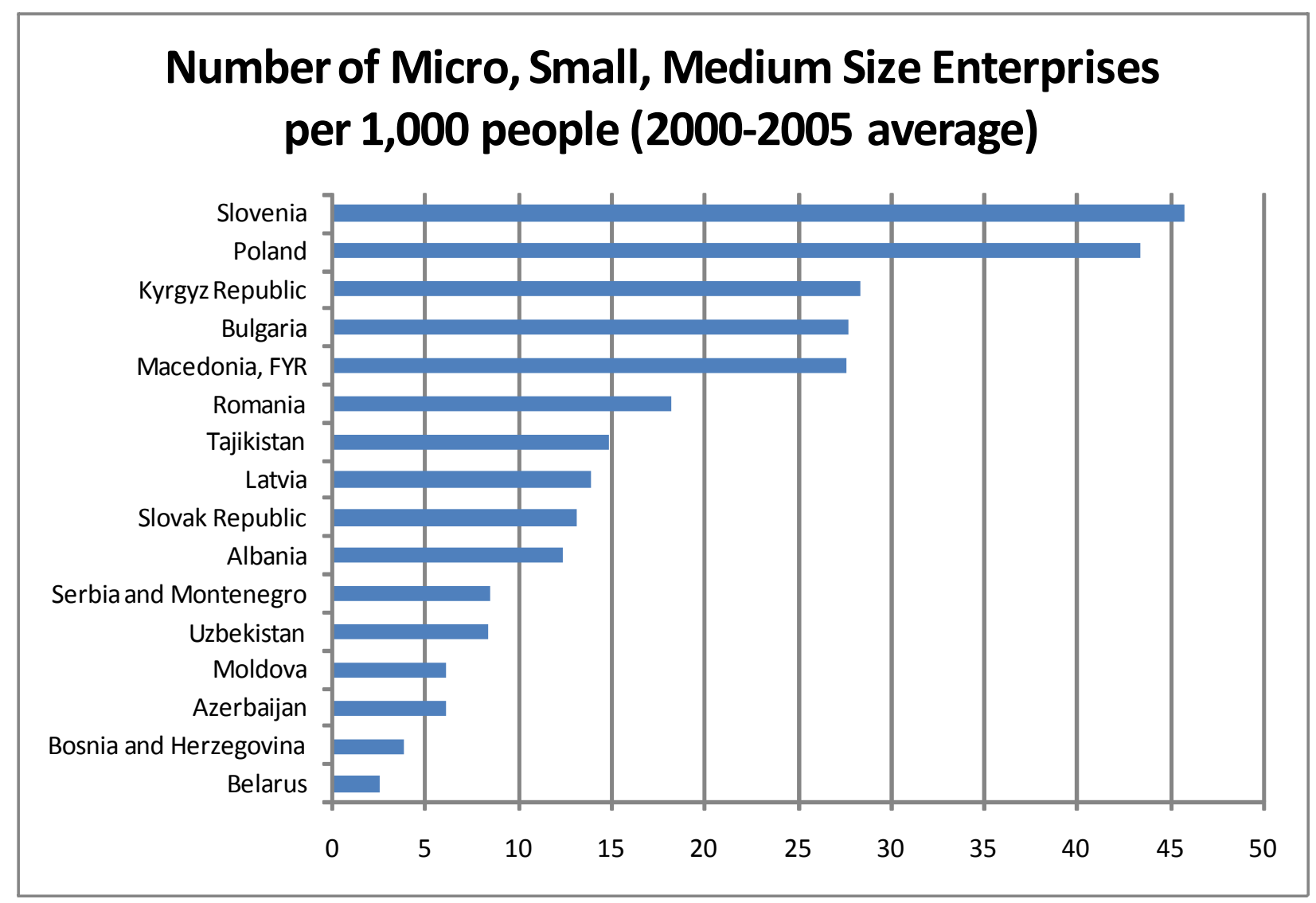

Source: Averages computed on the basis of World Bank, World Development Indicators. 
Figure 2 Start-ups (nascent entrepreneurs) and owners-managers of baby businesses (of ventures not older than 3.5 years) as percentage of working age population (WAP)

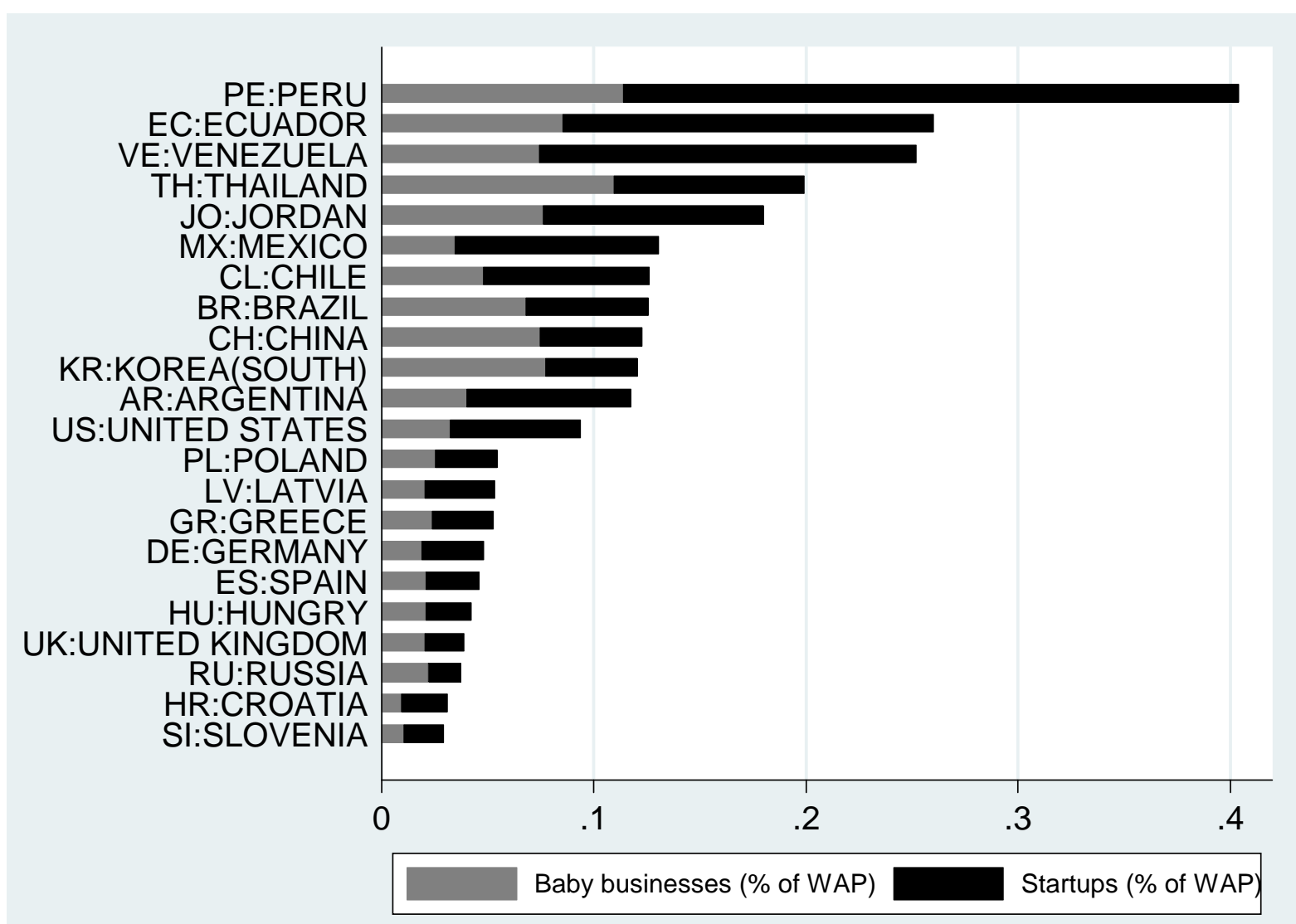

Source: Country averages for 1998-2005 calculated over individual Global Entrepreneurship Monitor (GEM) data. For more details on GEM methodology see Reynolds et al. (2005). 
Figure 3 Attitudes

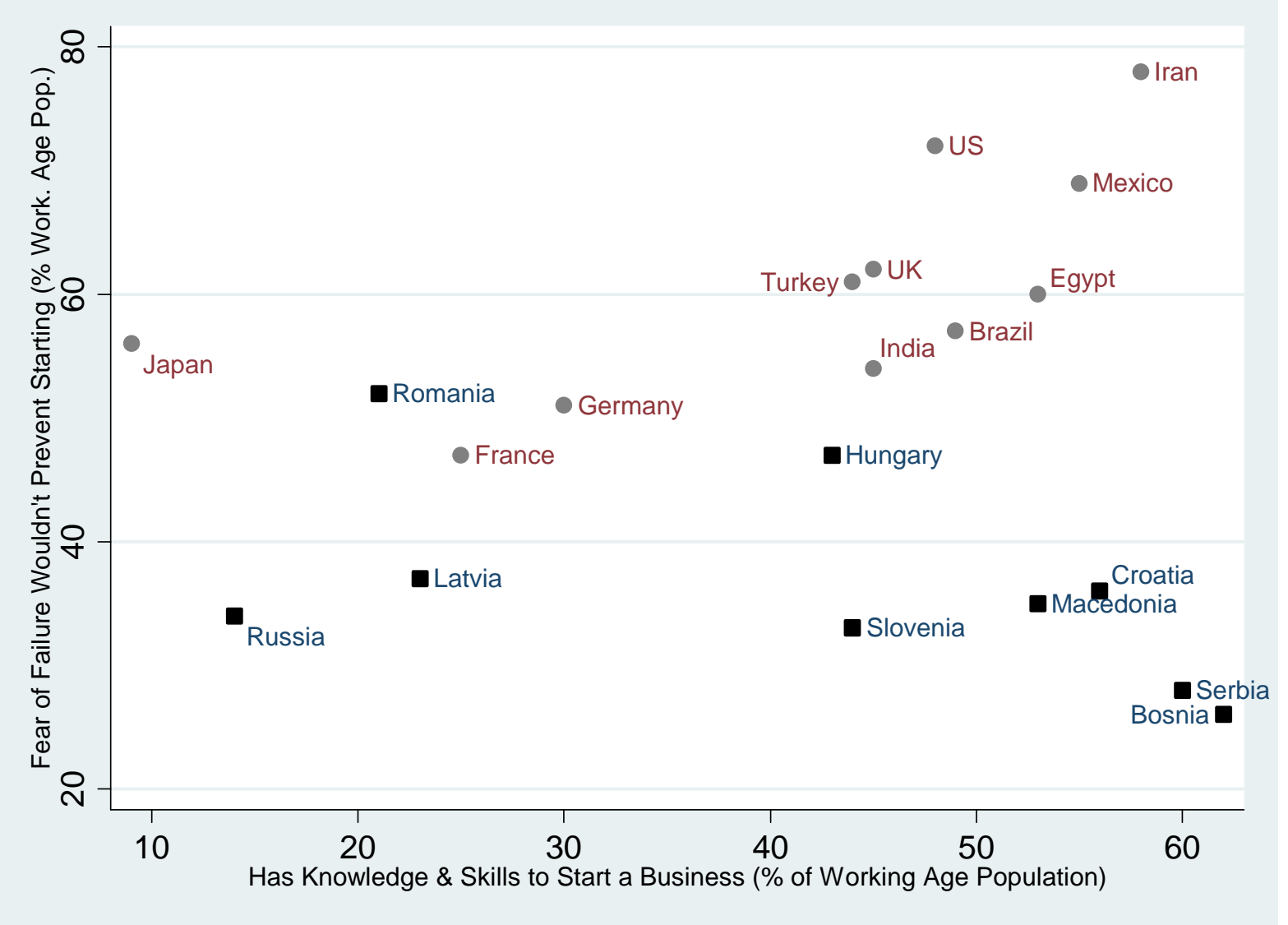

Source: Country averages, Global Entrepreneurship Monitor data for 2008, based on Bosma et al. (2008). 
Figure 4 Dismantling institutions: factors based on Heritage / Wall Street Journal Indicators

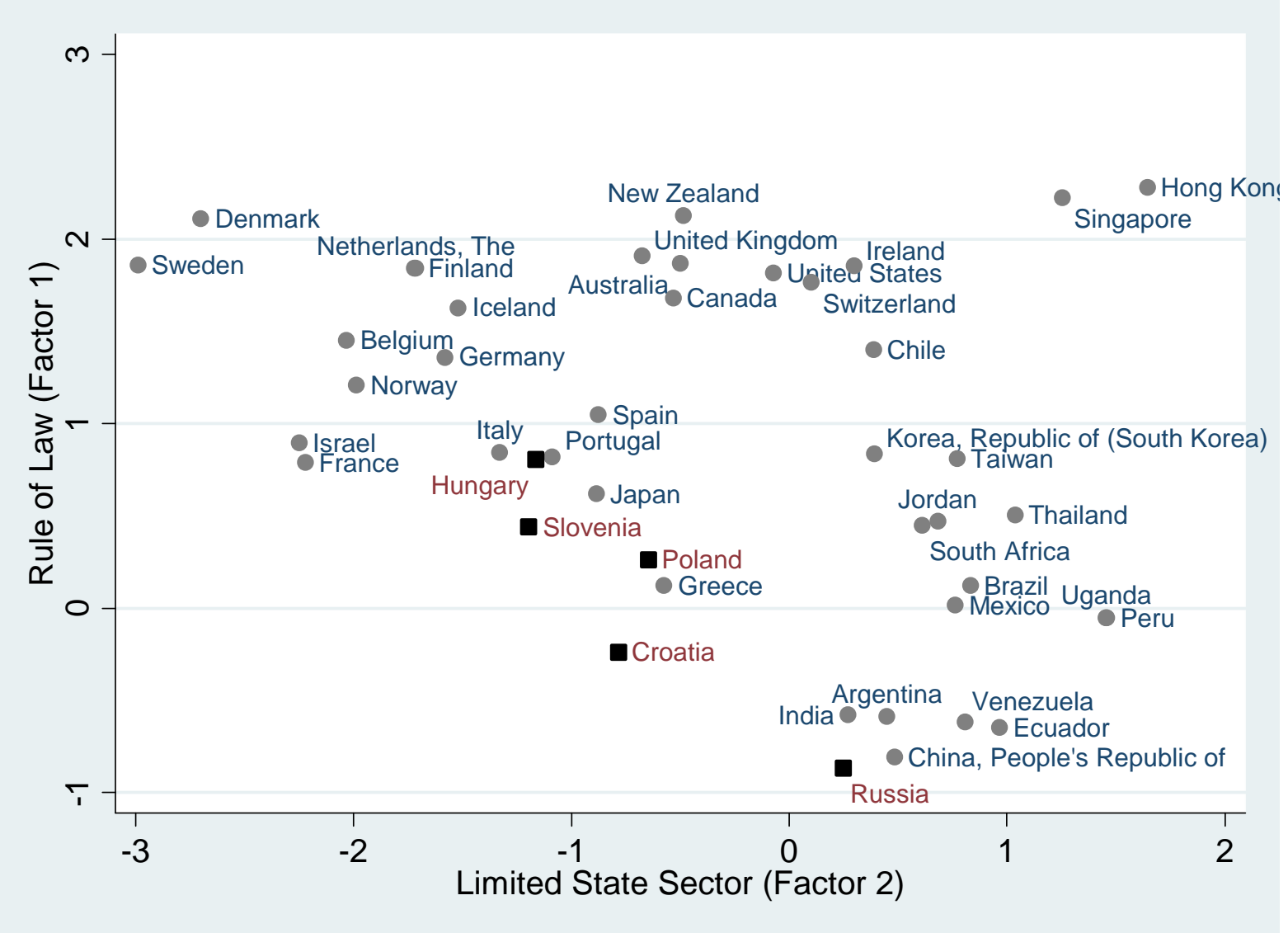

Source: Factors extracted by authors based on Heritage / Wall Street Journal Indicators. Aidis et al. (2009) provide details on methodology. The graph presents factor scores for GEM countries for 2004 or latest available. 
Figure 5 Property rights

Regression of property rights (2008) on In(GDP pc ppp) in 2007 Residuals for transition economies:

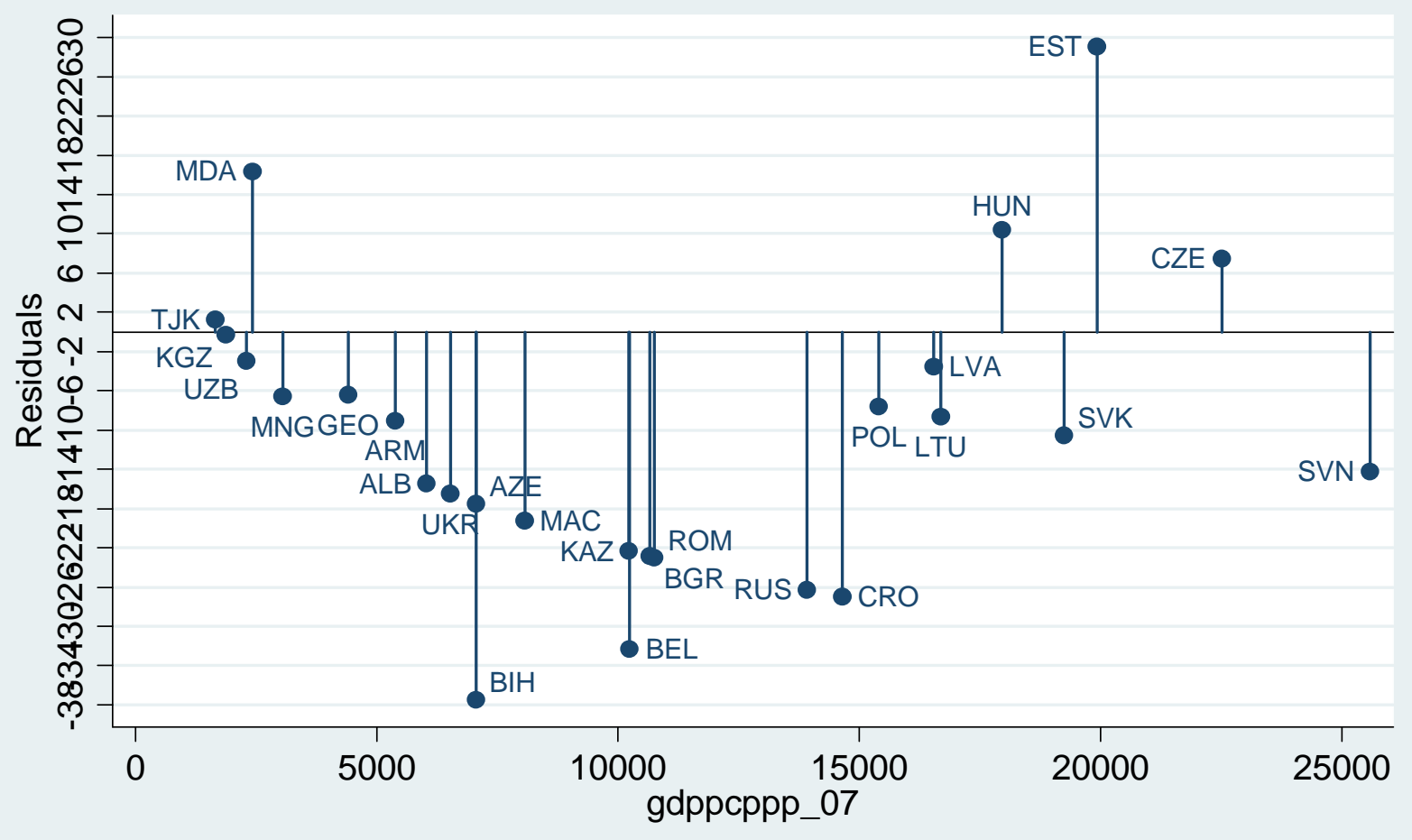

Source: Authors' calculations. GDP per capita data is from World Bank, World Development Indicators. Property rights indicators come from Heritage Foundation / Wall Street Journal. 
Figure 6 Freedom from corruption

Regression of freedom from corruption (2008) on In(GDP pc ppp) in 200\% Residuals for transition economies:

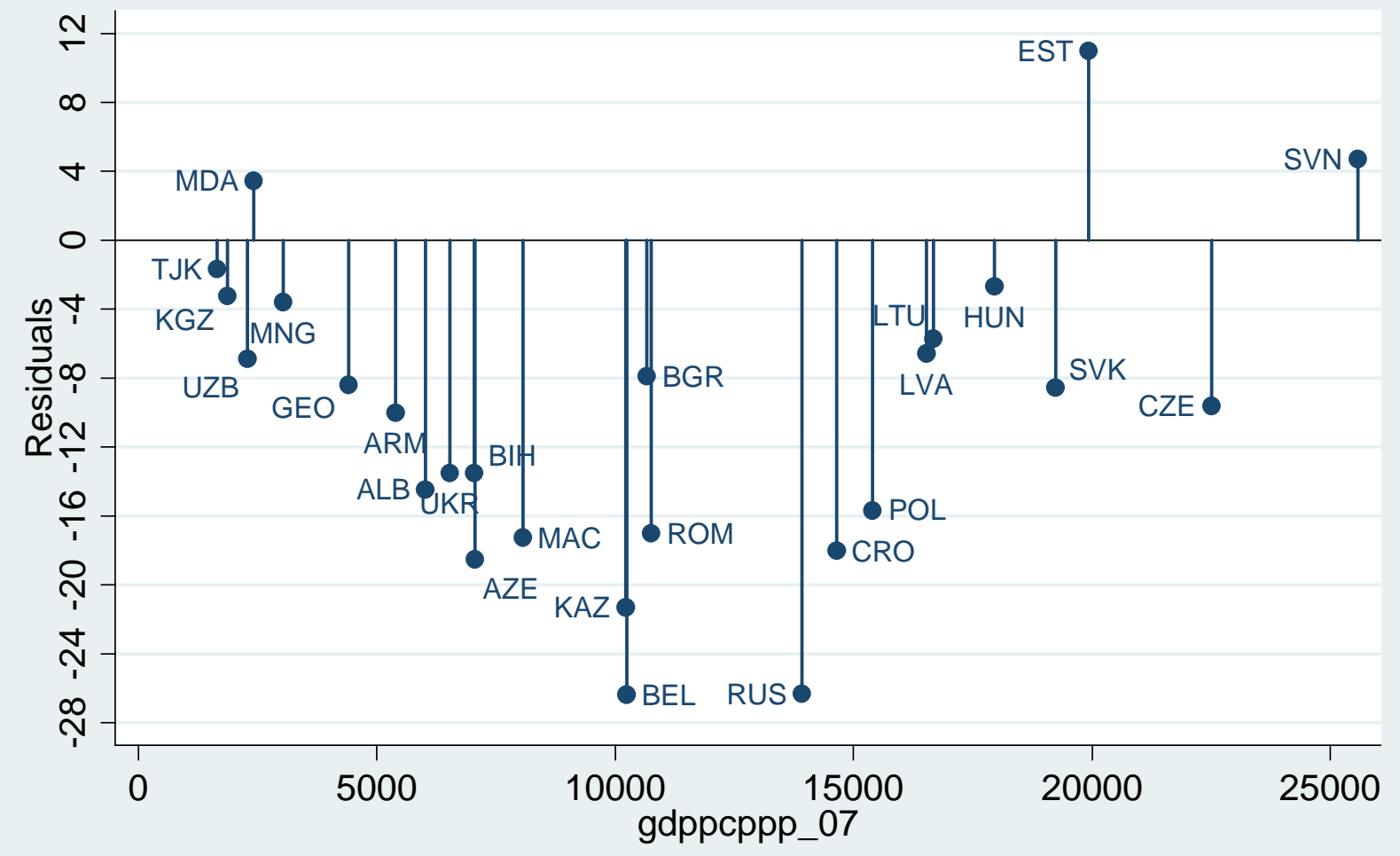

Source: Authors' calculations. GDP per capita data is from World Bank, World Development Indicators. Freedom from corruption indicators come from Heritage Foundation / Wall Street Journal. 
Figure 7 The extent of formal and informal finance, 1998-2004 averages.

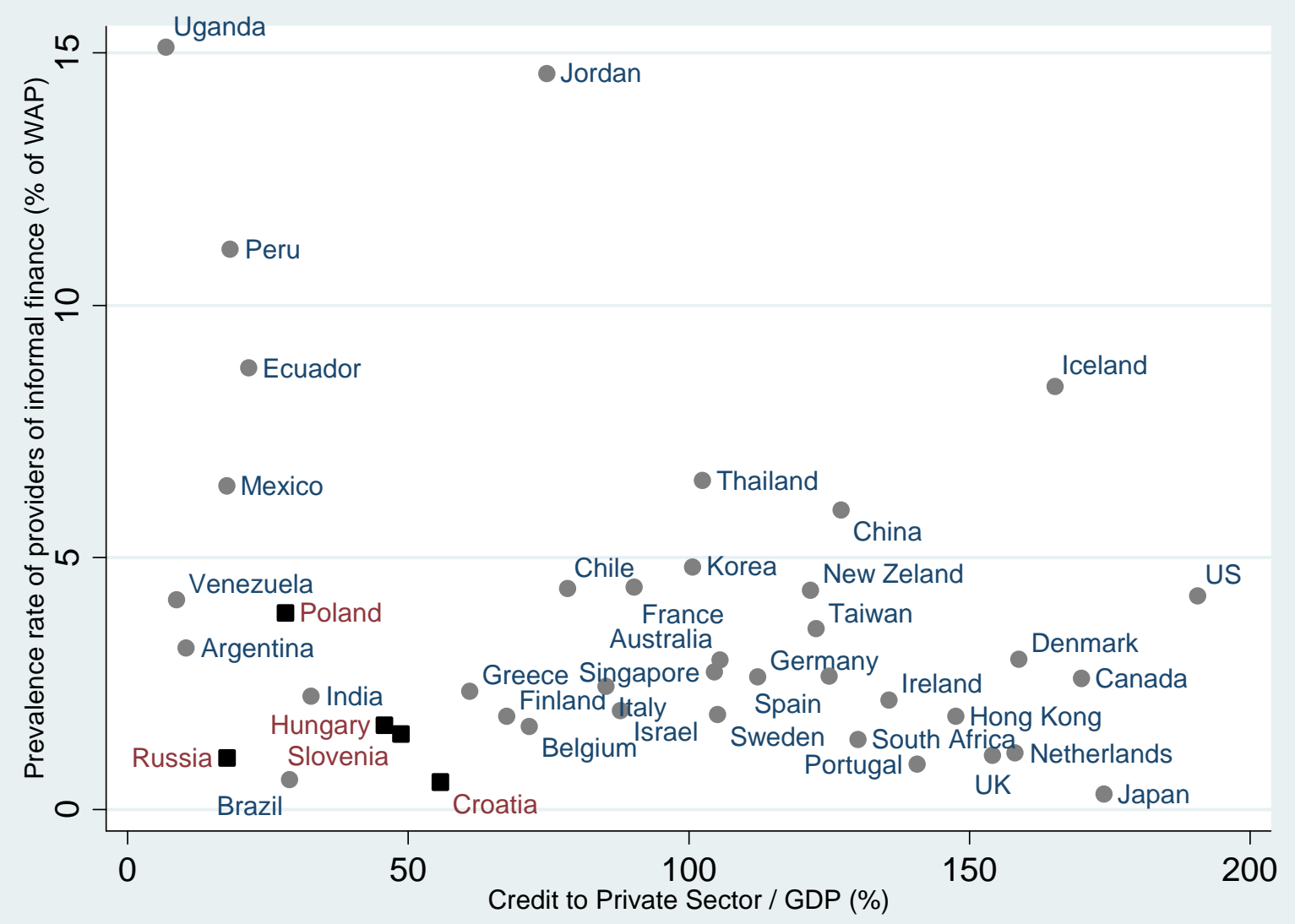

Source: Informal finance - prevalence rates of providers of informal finance for start-ups (within 3 year prior to survey) in working age population, authors" calculation based on GEM 1998-2004 consolidated dataset; credit to private sector over GDP - 1998-2004 average based on World Bank, World Development indicators 
Table 1 Descriptive statistics (Global Entrepreneurship Monitor data)

\begin{tabular}{|c|c|c|c|c|c|c|c|c|c|c|}
\hline & \multicolumn{5}{|c|}{ whole sample } & \multicolumn{5}{|c|}{ transition economies } \\
\hline & Obs & Mean & Std. Dev. & Min & Max & Obs & Mean & Std. Dev. & Min & Max \\
\hline Start-up (nascent entr.) & 503466 & 0.033967 & 0.181143 & 0 & 1 & 29143 & 0.022578 & 0.148557 & 0 & 1 \\
\hline Age & 471037 & 42.97038 & 16.98859 & 1 & 104 & 27131 & 42.43157 & 15.9094 & 14 & 99 \\
\hline Male & 503466 & 0.474405 & 0.499345 & 0 & 1 & 29143 & 0.479807 & 0.499601 & 0 & 1 \\
\hline In employment & 484814 & 0.494662 & 0.499972 & 0 & 1 & 29072 & 0.511282 & 0.499881 & 0 & 1 \\
\hline Education: secondary or more & 460982 & 0.670254 & 0.470121 & 0 & 1 & 29114 & 0.630075 & 0.482792 & 0 & 1 \\
\hline Education: postsec. or more & 460982 & 0.318466 & 0.465882 & 0 & 1 & 29114 & 0.187848 & 0.390597 & 0 & 1 \\
\hline Business angel in past 3 years & 501983 & 0.026804 & 0.16151 & 0 & 1 & 29028 & 0.016949 & 0.129083 & 0 & 1 \\
\hline Owner/man. of exist. business & 503466 & 0.049543 & 0.216998 & 0 & 1 & 29143 & 0.035137 & 0.184129 & 0 & 1 \\
\hline Log GDP pc (ppp) & 503466 & 26350.55 & 9928.6 & 802.63 & 46610.23 & 29143 & 14404.38 & 4028.307 & 9075.99 & 22132.83 \\
\hline $\begin{array}{l}\text { Annual GDP growth rate } \\
\text { Informal finance prevalence }\end{array}$ & 503466 & 2.950716 & 2.45264 & -10.89 & 10.06 & 29143 & 4.114909 & 1.294728 & 1.3 & 5.58 \\
\hline rate & 503466 & 0.026791 & 0.020294 & 0.002712 & 0.151122 & 29143 & 0.01693 & 0.009075 & 0.00503 & 0.038981 \\
\hline Property rights & 503466 & 78.50933 & 17.70456 & 30 & 90 & 29143 & 51.83303 & 16.081 & 30 & 70 \\
\hline Fiscal freedom & 503466 & 58.38507 & 14.78121 & 29.8 & 93.8 & 29143 & 65.84733 & 8.844043 & 51.8 & 84.9 \\
\hline Rule of law (factor 1 ) & 503466 & 1.259747 & 0.751559 & -0.86875 & 2.281132 & 29143 & 0.195716 & 0.566711 & -0.8687 & 0.852315 \\
\hline Limited state sector (factor 2) & 503466 & -0.87823 & 1.165031 & -3.27673 & 1.710471 & 29143 & -0.73553 & 0.438341 & -1.2550 & 0.247147 \\
\hline
\end{tabular}


Table 2 Estimation results. Dependent variable: probability of an individual in a country being a nascent entrepreneur

\begin{tabular}{|c|c|c|c|c|c|c|c|c|c|c|c|c|}
\hline & & (1) & & & (2) & & & (3) & & & (4) & \\
\hline Explanatory variables & $d F / d x$ & & $\begin{array}{l}\text { Robust } \\
\text { Std.Err. }\end{array}$ & $d F / d x$ & & $\begin{array}{l}\text { Robust } \\
\text { Std.Err. }\end{array}$ & $d F / d x$ & & $\begin{array}{l}\text { Robust } \\
\text { Std. Err. }\end{array}$ & $d F / d x$ & & $\begin{array}{l}\text { Robust } \\
\text { Std.Err. }\end{array}$ \\
\hline Age & 0.0007 & $*$ & 0.0003 & 0.0006 & + & 0.0003 & 0.0007 & $*$ & 0.0003 & 0.0006 & + & 0.0003 \\
\hline Age squared & -.00001 & $* * *$ & 0.0000 & -.00001 & $* * *$ & 0.0000 & -.00001 & $* * *$ & 0.0000 & -.00001 & $* * *$ & 0.0000 \\
\hline Male & 0.0154 & $* * *$ & 0.0008 & 0.0153 & $* * *$ & 0.0008 & 0.0154 & $* * *$ & 0.0008 & 0.0153 & $* * *$ & 0.0008 \\
\hline In employment & 0.0076 & $* * *$ & 0.0016 & 0.0081 & $* * *$ & 0.0016 & 0.0075 & $* * *$ & 0.0016 & 0.0080 & $* * *$ & 0.0016 \\
\hline Education: secondary or more & 0.0050 & $* * *$ & 0.0015 & 0.0046 & $* *$ & 0.0015 & 0.0050 & $* * *$ & 0.0014 & 0.0045 & $* *$ & 0.0015 \\
\hline Education: postsec. or more & 0.0080 & $* * *$ & 0.0012 & 0.0080 & $* * *$ & 0.0012 & 0.0080 & $* * *$ & 0.0012 & 0.0080 & $* * *$ & 0.0012 \\
\hline Business angel in past 3 years & 0.0518 & $* * *$ & 0.0040 & 0.0517 & $* * *$ & 0.0040 & 0.0515 & $* * *$ & 0.0040 & 0.0515 & $* * *$ & 0.0040 \\
\hline Owner/man. of exist. business & 0.0024 & & 0.0018 & 0.0025 & & 0.0018 & 0.0018 & & 0.0018 & 0.0019 & & 0.0018 \\
\hline Log GDP pc (ppp) & 0.0000 & & 0.0000 & 0.0000 & & 0.0000 & 0.0000 & & 0.0000 & 0.0000 & & 0.0000 \\
\hline Annual GDP growth rate & -0.0011 & $* * *$ & 0.0003 & -0.0010 & $* * *$ & 0.0003 & -0.0011 & $* * *$ & 0.0003 & -0.0010 & $* * *$ & 0.0003 \\
\hline Informal finan. prevalence rate & 0.3264 & $* * *$ & 0.0735 & 0.3130 & $* * *$ & 0.0720 & 0.3244 & $* * *$ & 0.0728 & 0.3112 & $* * *$ & 0.0714 \\
\hline Property rights & -0.0002 & & 0.0001 & & & & -0.0002 & & 0.0001 & & & \\
\hline Fiscal freedom & 0.0004 & $* * *$ & 0.0001 & & & & 0.0004 & $* * *$ & 0.0001 & & & \\
\hline Rule of law (factor 1 ) & & & & -0.0024 & & 0.0027 & & & & -0.0025 & & 0.0027 \\
\hline Limited state sector (factor 2 ) & & & & 0.0058 & $* * *$ & 0.0011 & & & & 0.0058 & $* * *$ & 0.0011 \\
\hline Transition & -0.0096 & $* *$ & 0.0029 & -0.0067 & $*$ & 0.0030 & -0.0184 & $* *$ & 0.0043 & -0.0172 & $*$ & 0.0047 \\
\hline Age $*$ Transition & & & & & & & 0.0013 & $*$ & 0.0006 & 0.0013 & $*$ & 0.0006 \\
\hline Age squared $*$ Transition & & & & & & & -.00002 & $* *$ & 0.0000 & -.00002 & $* *$ & 0.0000 \\
\hline Number of observations & 434222 & & & 434222 & & & 434222 & & & 434222 & & \\
\hline Wald Chi squared & 1831.73 & $* * *$ & & 1885.7 & $* * *$ & & 2133.54 & $* * *$ & & 2182.02 & $* * *$ & \\
\hline Log pseudo-likelihood & -57106 & & & -57062 & & & -57087 & & & -57044 & & \\
\hline Pseudo R2 & 0.0932 & & & 0.0939 & & & 0.0935 & & & 0.0942 & & \\
\hline
\end{tabular}


Notes to Table 2:

a. The table reports marginal mean effects, except that for dummy variables the reported effects are those of switching from zero to one.

b. Robust standard errors clustered on country-years.

c. $* * *$ Significant at $0.001,{ }^{* *}$ significant at $0.01,{ }^{*}$ significant at $0.05,+$ significant at 0.10 . 